\title{
Compassion: A Neglected Motivator for Sustainable Tourism
}

David Bruce Weaver ${ }^{1,2} \&$ Xin (Cathy) Jin ${ }^{1}$

${ }^{1}$ Department of Tourism, Sport and Hotel Management

Griffith University - Gold Coast campus

Southport, Qld. Australia 4222

${ }^{2}$ Corresponding author

d.weaver@griffith.edu.au

Tel: +61 (0)7 55529290

Fax: +61 (0)7 55528507

David Weaver is a Professor of Tourism Research specializing in sustainable tourism, ecotourism, resident perceptions and destination management. He is a Fellow of the International Academy for the Study of Tourism

Xin (Cathy) Jin is a Lecturer in the Department of Tourism, Sports and Hotel Management at Griffith University in Australia. Her two main areas of research interest are destination marketing and event management. 


\begin{abstract}
Compassion is defined and identified in this paper as a powerful and universal motivator for actions that could help attain sustainable outcomes and enable aspirational forms of sustainable tourism, including just tourism, hopeful tourism and enlightened mass tourism that have not yet demonstrated real-world traction. Despite its potential, compassion has been neglected in the tourism literature. This paper reviews the 50 year quest for a "better tourism", and presents a compassion-scape as a comprehensive and systematic framework for facilitating sector engagement with compassion. "Context" factors associated with tourism settings (e.g. level of development, purpose) and agents (e.g. mindset, psychographics, motivations) influence "encounter" elements such as the relationship, type, and distress characteristics. Subsequent "response" factors such as type, recipient, timeframe and intention influence the "implications" for sustainable tourism, which in turn affect the types of "intervention" (e.g. mindful interpretation, social marketing, faith injunction) implemented to achieve sustainable outcomes. The many innate methodological challenges for the researcher in measuring compassion are discussed, along with the issues involved in operationalizing the compassion-scape to engage and reform alternative tourism forms, notably volunteer tourism, pro-poor tourism, religious tourism and fair trade tourism as well as conventional mass tourism. A paper for the thinking reader.
\end{abstract}

Keywords: compassion, ethics, sustainable development, motivation

\title{
Introduction
}

Growing dissatisfaction with conventional mass tourism as an effective vehicle for attaining holistic sustainable development goals has been a major trend in the tourism 
literature since the 1970s. Accusations include high revenue leakage (induced by high import levels and external control of the business), "drought/deluge" cycles of seasonality, inequitable distributions of benefits, and the dominance of unskilled and low-wage local employment (Bryden, 1973; Lea, 1988; Matheson \& Wall, 2006). Increased commodification, demonstration effects and crime, and eroded "sense of place" are among the affiliated socio-cultural costs (de Kadt, 1984; Matheson \& Wall, 2006; Pizam, 1978; Smith, 1989), while negative environmental impacts include the widespread alteration and degradation of habitat (Bramwell, 2004; Butler \& Boyd, 2000; Pearce, 1989), and the production of waste residuals such as carbon dioxide which exacerbate climate change (Becken \& Hay, 2007; Scott, Hall \& Gössling, 2012). Since the early 1990s, "sustainable tourism" has been engaged as a platform for reform. Such engagement has included proposals for various allegedly more desirable activities such as "just tourism", "hopeful tourism" and "slow tourism" which emphasize engagement with moral principles, or ethics. Few of these to date, however, have gained traction or demonstrated real progress toward the attainment of sustainability despite their intrinsic merits. It is argued here that a contributing reason, and one that is applicable to sustainable tourism more generally, is the lack of an enabling precursor that motivates or compels actors to behave in ways consistent with and conducive to the realization of the espoused ideology. We identify this missing precursor as compassion, and provide the first tourism research paper to engage with this construct and conceptualize it as a potent enabler of sustainable tourism. Methodologically, we begin by critically reviewing aspirational forms of sustainable tourism and their attendant lack of traction. The construct of compassion is subsequently described with an emphasis on its capacity to induce behavior compatible with sustainability outcomes. The engagement with compassion in the tourism literature is then assessed. Informed accordingly, the contours of a "compassion-scape" are presented as a framework and agenda for implementation. 


\section{The Quest for "Better" Tourism}

According to Jafari (2001), the development of tourism after World War Two was informed by an "advocacy platform" which privileged the sector as a relatively risk-free vehicle for achieving economic development, particularly in peripheral regions. The negative consequences of unregulated development, however, subsequently spawned a "cautionary platform" in the 1970s that critiqued laissez-faire mass tourism, and was followed by an ideologically-affiliated "adaptancy platform" in the 1980s which espoused "alternative tourism" activities such as ecotourism, homestay tourism and cultural village tourism as more appropriate options (Hardy, Beeton \& Pearson, 2002). Supporters of alternative tourism have emphasized its opposition and superiority to mass tourism, and as such display conflict-based dialectics, aspiring that it should supplant conventional mass tourism to achieve more desirable local outcomes. It has been commonly contended, for example, that if large-scale tourism would foster destructive economic leakages, then small-scale alternative tourism would instead promote beneficial economic linkages, and community empowerment rather than dependency. Weaver (2014), however, building on earlier critiques such as Smith and Eadington (1992), contends that alternative tourism has failed as a viable alternative to mass tourism and has been discredited due to unrealistic and unrealized outcomes, inherent diseconomies of scale, and dependency on the mass tourism support systems it disdains, such as the major airlines. "Justice tourism" (Higgins-Desbiolles, 2008; Scheyvens, 2002), a crossproduct manifestation in which radical aspirations of a new anti-capitalist global order are particularly explicit, is similarly demonstrating a lack of uptake beyond the rhetoric of its enthusiastic academic advocates, an outcome that also reflects the conservatism and vested interests of most tourists and tourism stakeholders.

The emergence in the 1990s of the "knowledge-based platform" is associated with the aspirational ascendancy of "sustainable tourism". Concepts such as justice tourism attest that 
sustainable tourism is often still framed in an unadulterated context of alternative tourism that perpetuates conflict-based dialectics. However, increasingly prevalent are proposed forms of tourism that pragmatically combine elements of alternative and mass tourism, thereby indicating resolution-based dialectics (Weaver, 2014) and an evolutionary rather than revolutionary approach to achieving sustainable tourism that reflects the above-mentioned conservatism of most tourists (Weaver, 2012). An early example, and one that exemplifies a subsequent emphasis on ethics (or "ethicality") as the critical alternative tourism ingredient in such syntheses, is "just tourism", described by Hultsman (1995) as "fair, honourable, upright [and] proper" (p. 560), and a sound paradigmatic basis for developing principled operational codes of behavior and marketing that facilitate sustainable outcomes, including for the natural environment. This transcends the economic dimension that is imperative to conventional mass tourism. "Altruistic tourism" has similar connotations but was applied in the specific context of volunteer tourism in the Himalayas (Singh, 2002), thereby privileging more the alternative side of tourism spectrum. "Hopeful tourism" is positioned by Pritchard, Morgan and Ateljevic (2011) as a values-led humanist perspective or "unfolding vision" that can lead to societal transformation ("regime change") through imbued principles of partnership, reciprocity and respect that challenge the hegemonic neo-liberalism and power structures of contemporary tourism management discourses. However, scrutiny of this ontological framework reveals a more subtle dialectic of disruption and balance. For example, it embraces multiple perspectives, redefines the relationship between the intuitive and the rational and "offers an alternative to the dominant way of understanding and being in the tourism world not by discarding or dismissing it [our italics] but by engaging it to demonstrate that it offers but one perspective" (p. 953).

Macbeth (2005) moves beyond Jafari's four platforms by focusing on a philosophy of ethics, or "value-full" platform, in which industry "must combine a moral position with the 
scientific, technical positions currently involved" (p. 973) if it is serious about sustainable development. This assertion is based on an understanding that all human actions are directly or indirectly ethics-informed. Similarly dialectical, but more in line with conventional neoliberal ideology and hence replicated in institutional rhetoric (Harrison, 2008), are "propoor tourism" (Ashley, Roe \& Goodwin, 2001) and "fair trade tourism" (Cleverdon \& Kalisch, 2000). Both place poverty alleviation at the core of tourism policy and seek to redress inequitable terms of exchange between North (global core) and South (global periphery) through commodity-focused ethics. "Slow tourism" (Lumsdon \& McGrath, 2011; Matos, 2004) is more implicitly ethical and emphasizes decelerated travel experiences to produce more positive social, psychological and environmental results for destinations and tourists. Finally, resolution-based dialectics are most explicit in "enlightened mass tourism" (Weaver, 2014), where the amalgamation of the "best" aspects of mass tourism, and especially economies of scale, with those of alternative tourism - and ethics in particular - is advocated. This supports, for example, the embrace and synthesis of both objective and subjective perspectives on tourism development.

Little real world traction is evident in the adoption of either the radical or dialectically-informed sustainable tourism options except perhaps for fair trade and pro-poor tourism. Higgins-Desbiolles (2008), however, alleges that these have been "usurped" by conventional tourism interests for green-washing purposes. Chambers and Buzinde (2015), more generally, lament the lack of radical activism in tourism academia. Beyond the newness of some of these models, factors underlying this inertia include the lack of specific directives about operationalization in diverse tourism contexts, and the paucity of vested marginalized voices (such as females of color) within the academic community. Also germane, if disconcerting, is the possibility of widespread satisfaction (or at least lack of dissatisfaction) with the tourism status quo, wherein the rhetoric of sustainability and moral responsibility has 
been universally embraced and opportunistic environmentalism and activism are commonplace and visible in the industry. This "paradigm nudge", exemplified by the ubiquity of linen re-use initiatives in hotels (Goldstein, Cialdini \& Griskevicius, 2008), appears to mirror on the demand-side the veneer environmentalism of consumers concerned about contemporary environmental and social issues but insufficiently motivated to significantly alter their travel behavior accordingly (Weaver, 2007). On the supply-side, resident surveys in diverse settings consistently reveal majority satisfaction with and support for the local tourism sector based on perceptions, as per social exchange theory, that economic benefits outweigh the accompanying social and environmental costs (Deery, Jago, \& Fredline, 2012; Easterling, 2005). This pertains even in areas of intensive development and high tourist-to-resident ratios, in developing economies such as the Maldives (Shakeela \& Weaver, 2012) and during "mature" stages of development (Aguiló \& Rosselló, 2005). The transactional attraction, accommodation and satisfaction of tourists, accordingly, are prioritized over the prevention and management of negative destination impacts. The latter are largely dismissed as the inevitable costs of doing business which can be addressed on a piecemeal basis to the extent that they significantly diminish satisfaction and profitability.

Does it therefore hold that reform - through a concerted search for better tourism - is unnecessary? The argument to the contrary considers that residents do acknowledge local environmental and social costs, and that losers almost inevitably emerge among the winners. Critical tourism academics, from a more systemic perspective, lament the persistence of fundamentally inequitable distributions of power and resources (Chambers \& Buzinde, 2015). In either case, continued high levels of tourism growth, increased dependency on this sector, and globalized structures of organization and supply - all logical consequences of a still fundamentally transactional philosophy of business - suggest that uncertain outcomes are more likely and that, therefore, collateral damage (sustained while pursuing the 
satisfaction/profit nexus) will increase, as will the negative global consequences of higher greenhouse gas emissions and increased stress on natural resources. A stronger and more urgent emphasis on ethics, as embodied in concepts such as just tourism, hopeful tourism and enlightened mass tourism, is therefore warranted in order to transcend this pervasive transactionalism and the tokenism that Frynas (2005) argues is embodied in most contemporary Corporate Social Responsibility (CSR) strategies. Behaving more ethically is commonly advocated as "the right thing to do" for all stakeholders, and transactionalism in principle accommodates such behavior through the logic of reciprocal altruism, or the exchange of goods and services for mutual benefit (Trivers, 1971) as well as through egocentric and egoistic theories of altruism (Khalil, 2004). However, it is argued here that given the mechanistic implications of transactionalism these are insufficient for assuring genuinely sustainable outcomes, and that the latter is more likely to be attained through the evocation of transactionalism-transcendent compassion, as discussed subsequently.

\section{Compassion}

Compassion is defined by Goetz, Kelner and Simon-Thomas (2010) as "the feeling that arises in witnessing another's suffering and that motivates a subsequent desire to help" (p. 351). They situate compassion as a distinctive emotional state similar to, but different from, empathy, sympathy or pity, and one which has developed through evolutionary processes that enable offspring survival and community cooperation. Kanov, Maitlis, Worline, Dutton, Frost and Lilius, (2004) similarly define compassion as an "empathic emotional response elicited by another person's suffering that moves people to act in a way that will ease the person's anguish or make it more tolerable" (p. 814). Again, the role of compassion as a motivator of remedial actions and "deliberate participation in another 
person's suffering" (Von Dietze \& Orb, 2000, p. 168), a condition that is not inherent to empathy per se (Eisenberg \& Miller, 1987), is salient. From either definition it can be conceptualized (and operationalized) as a process involving sequential cognitive, affective and conative sub-processes of noticing, feeling, and (intended or actual) responding in a prosocial manner (Clark, 1997). "Responding" in some cases entails "non-responding", as in not venting anger, not littering, spreading gossip or deliberately causing inconvenience or harm to others. Some speculate that compassion is both a temporary state, triggered by circumstance, and also an enduring trait, cultivated perhaps through the accumulated experience of prior compassionate states (Goetz, Kelner \& Simon-Thomas, 2010). Gilbert (2005), less ambiguously, grounds compassion in a pervasive care-giving mentality that is sensitive to distress and involves a combination of facilitative motives, emotions, thoughts, and behavior. As such, and critically for achieving sustainability outcomes, it is cerebrally grounded in altruistic moral principles (Eisenberg \& Miller, 1987; Von Dietze \& Orb, 2000) and serves as a persistent rather than simply ephemeral motivator.

Kanov et al (2004) note that compassion is a central theme in all major religious traditions - as for example in variants of the Golden Rule in Christianity, Judaism and Islam, and the Confucian concept of ren - and is at the heart of what it is to be fully human. However, they also argue, like Goetz, Kelner and Simon-Thomas (2010), that it must be cultivated, whether or not the capacity to be compassionate is innate. In practice this usually entails initial expression toward loved ones and gradual extension to other humans and then other sentient beings such as animals (Duffy \& Moore, 2011; Fennell, 2014; Von Dietze \& Orb, 2000) and beyond (Wallace, 2005), including oneself. Indeed, some degree of selfinterest is usually implicit if not overt in evolutionary (reproduction, survival, "feel good" effect) as well as spiritual explanations (reward of a blissful afterlife) of compassionate behavior, implying cost/benefit calculations, if not baldly transactional ones, as precursors to 
action along with altruism; self-interest and altruism, in most compassion discourses, are not posited as mutually exclusive. Usually expressed toward other humans, compassion can also be invoked and evoked in relation to other or all living beings, and even "non-living" entities such as the earth or cosmos.

The "compassionate individual", ideally, behaves compassionately at all times, but in practice the degree of feeling and response depends on such factors as what is noticed (e.g., drastic and immediate suffering versus chronic, low-level discontent), how it is noticed (e.g., direct observation versus being informed by others, or through the media) and ability to respond (e.g., proximity, financial resources, physical ability) (Gilbert, 2005). Compassion is also most likely to be projected when the victims are similar to us, when we like them, and/or if we have personal experience of the kind of pain being noticed (Goetz, Kelner \& SimonThomas, 2010). Other alleged conditions of compassionate response, and similarly related to evolutionary theories of development, are assessments of deservingness, coping abilities of the afflicted, and the ability to tolerate distress so that neither withdrawal nor "overcompensation" occur (Gilbert, 2005). Females (Goetz, Kelner \& Simon-Thomas, 2010) and younger adults (Grühn et al, 2008) have also been found to be more conducive to compassionate behavior due to higher attributed levels of empathy, although Hume (2010) contends that "Generation Y" members exhibit disparity between expressed compassionate sustainability values and actual unsustainable consumption patterns.

\section{Compassion and Tourism}

What then has been the engagement with compassion in tourism research? Framed above as a compelling motivator to act in ways that alleviate suffering and distress (Miller, Grimes, McMullen \& Vogus, 2012; Omoto, Malsch \& Barraza, 2009), compassion offers a potentially powerful and seemingly universal basis on which to attain sustainability outcomes 
provided that suitable levels of noticing, feeling and responding can be elicited. Its explicit presence in the tourism literature, however, is almost non-existent. For example, compassion is not mentioned in any of the tourism models outlined above, although hopeful tourism does explicitly embrace the cognate ethic of love (Pritchard, Morgan \& Ateljevic, 2011). Mostafanezhad (2013) refers to "the rhetoric of compassion that mediates the volunteer tourism experience" (p.322) and enticingly describes the latter as a "compassionate form of touristic consumption” (p.326), but provides no further interrogation beyond describing compassion as "a highly mediated, political and complex experience" (p.326) that privileges sub-Saharan Africa as an exemplar of suffering and need. The term "compassionate tourism" is used by Nankervis (2009) to describe the mobilization of domestic and foreign social capital in tsunami-affected destinations on the coast of Thailand following the 2004 Boxing Day disaster. But again, no further analysis or empirical investigation is offered, even though this provides possible case study evidence of pro-social outcomes arising from spontaneous compassionate behavior by tourism stakeholders.

Farbotko (2010) describes how compassion combines or competes with voyeurism in motivating climate change tourists to visit threatened Tuvalu, thereby pointing out, like Mostafanezhad (2013), the patronizing attitudes of Western tourists, but also the dualism which invokes self-interest as the complementary counterpart to altruism or "other-interest". An implicit imperative of compassion is also evident in industry discourses, illustrated by descriptions of discounted room rates for those affected by Hurricane Katrina in 2004 as the "right thing to do" even though the hotels lost money as a result (Gunter, 2005). Glover and Filep (2015) evoke intriguing linkages to compassion in their discussion of the "kindness of strangers in tourism". Here, the reference in the context of positive psychology and social capital is to the prevalence in tourism of fleeting experiences that focus only on the attainment of selfish stakeholder goals. The authors, however, argue that tourism is a suitable 
context for temporary social capital, between host and guest for example, to take shape, through acts of kindness between strangers. Often, beyond but built on hospitality traditions of generosity and magnanimity (Lashley \& Morrison, 2011), these occur as responses to "a challenging problem or exogenous shock" (p. 160) and spawn feelings of gratitude and thankfulness that increase the proclivity of both recipient and initiator to act kindly in future tourism experiences.

\section{Enabling Compassion in Tourism}

We position compassion as a compelling motivator for enduringly sustainable behavior and, accordingly, criticize its absence from contemporary tourism discourses. By way of redress, the remainder of this paper will present and discuss an inductive framework for engagement which complements the systems-based approach that Liu (2003) contends is required to improve the understanding and implementation of sustainable tourism. We describe this framework as a compassion-scape to capture qualities of comprehensiveness and interconnection (Figure 1). The context component of this compassion-scape considers both the type/location of the attendant tourism setting and the characteristics of the responsive tourist or resident "agent". The use of the latter term emphasizes the agency - or capacity and freedom to perform acts of compassion - that is latent in all tourism stakeholders. The encounter component implicates the agent-recipient vector, the type of exposure in the encounter, and the nature of the distress or suffering, while the response element entails the nature of the feeling, the goal(s), the scope and the timeframe of the action. The implications component considers the repercussions of these actions for attaining sustainable tourism outcomes. Finally, the intervention element discusses the vehicles through which compassionate behavior can be motivated. These components are now examined in detail. 
Figure 1 about here

\section{Context}

Tourism context (Box A) critically influences the compassion experience and has several distinct parameters. First, whether the setting is economically advanced or peripheral indicates the degree of poverty and related suffering that is likely to be present. However, enclave settings are widespread in the latter and discourage direct exposure (Mbaiwa, 2005). Indeed, critics of North-to-South tourism contend that such activity itself causes or exacerbates such distress (Mowforth \& Munt, 2008), so that being in a "Third World" setting, enclave or not, warrants a higher sense of moral suasion. Second, specific destination jurisdictions are relevant because of bylaws that influence the visibility of, and responses to, distress. Several New Zealand local governments, for example, have implemented punitive laws that target the homeless but also programs that provide them with social services (Laurenson \& Collins, 2007). Third, along a philosophical continuum, settings that emphasize alternative leisure tourism models such as just, justice and hopeful tourism should be compelled to promote compassionate behavior, though little if any tourism activity is explicitly labeled as such. More promising is volunteer tourism, although this has yielded mixed motivations and controversial outcomes (Grimm \& Needham, 2012; McIntosh \& Zahra, 2007; Wearing \& McGehee, 2013). "Slum tourism" and "orphanage tourism" are similarly contentious because of their potential for exploitation and connotations of voyeurism (Frenzel, Koens \& Steinbrink, 2012; Tourism Concern, 2014), with Reas (2012) equating orphanage tourism to a "fantasy" and "commercialization" of compassion.

A fourth factor is categorical travel purpose. Mass leisure tourism, as per the social capital concerns of Glover and Filep (2015), is more unabashedly hedonistic and self- 
interested, fostering mindsets less conducive to seeking out, noticing or responding compassionately to distress - why should one be pervasively and meaningfully compassionate while on holiday? Fundamentally, most stakeholders understand such tourism to be a commercial exchange between buyers and sellers where each actor tries to optimize personal outcomes. Accordingly, "altruism plays second fiddle to profits [and activity such as] pro-poor tourism therefore either needs to make a stronger ethical argument - where actions are founded on altruism as a non-negotiable principle, not mutual material benefits or else abandon the pretence entirely" (Chok, Macbeth \& Warren, 2007, p. 161). Engagement with impacts in tourism studies is largely focused on variants of leisure tourism for this reason and because of its ubiquity and magnitude, yet business and visiting friends and relatives (VFR) are together about as large globally as the former (Weaver \& Lawton, 2014). VFR tourism, a largely under-researched and under-estimated phenomenon (Backer, 2012), is more likely to occur in residential backstages where suffering and marginalization are often more salient (MacCannell, 1976). Notwithstanding contentions that empathy is an evolutionary response that increases offspring survival (Goetz, Kelner \& Simon-Thomas, 2010), the extent to which, and the dynamics by which, proximity to family and friends in tourism settings makes them the object of compassionate behavior or otherwise mediates the expression of such behavior is unclear.

Business tourism presents as even more explicitly transactional than leisure tourism, although formal CSR policies, paradoxically, confer expectations of adherence to ethical imperatives for adopting companies. Businesses, unlike individual leisure or VFR tourists, also often have access to resources that make possible long-term and substantial remedial actions. Pilgrimage and other faith-focused forms of tourism merit special attention given their intrinsic connotations of compassion. However, investigations into the behavior of Christian pilgrims in the Holy Land (Collins-Kreiner \& Kliot, 2000) shed no light on the 
expression of compassion by these tourists. The same pertains to studies of pilgrimages to Lourdes (Eade, 1992), or Thai Buddhist pilgrimage (Cohen, 1992) and "religious tourism" more generally (Raj \& Morpeth, 2007), although such research does yield findings that usefully contextualize future compassion-focused investigations. An exception is Din (1989), who frames Islam as a life-pervasive faith which positions compassion to visitors, pilgrims and otherwise, as an injunction, particularly within the Ummah (community of faithful). However, this author contends that the deep immersion of Muslim societies in Western capitalism and transactional tourism renders the ideal Muslim host as almost non-existent.

The parallel contextual consideration is agent profile (Box B). Beyond the idea of mindset, inculcating a broader sense of "mindfulness" that is responsive to suffering is also important, whether informed by faith or not (Langer, 1989). This in turn relates to the values, morals, beliefs and attitudes of individuals, and psychographic personality traits such as extraversion that have been correlated with empathy (Hogan, 1969). In contrast, high social power has been affiliated with lower compassion (Van Kleef et al, 2008). As with faith, to date these have not been interrogated in tourism studies within the context of compassion, although they are otherwise widespread in motivational and behavioral tourism research. Past experience with distress and degree of identification with the victim(s) influence coping ability and perceived deservingness, suggesting the importance of prior participation in activities such as volunteer tourism and orphanage tourism. Here, however, susceptibility to compassion fatigue is also important, given the incessant coverage of distress in the media and exposure to the same in some activities (Moeller, 1999). Personal ability to respond, including perceived self-efficacy (which also influences proclivity to travel), is also germane (Hung \& Petrick, 2012), as is fear of reprisal in situations where victimizers are present or punitive laws enforced. A more ephemeral agent characteristic is travel group composition. Campo-Martínez, Garau-Vadell and Martínez-Ruiz (2010) found that this variable influenced 
repeat visitation intentions, and it is likely that traveling alone, with friends, with spouse and children, or with a tour group, will also differentially affect the projection of compassion through factors such as peer pressure and exemplar role-playing. Motivations of the agent and other group members also affect the process by establishing priorities that dictate actions and responses. Finally, agent demographics are influential, as with the widespread contention that females are more likely to notice, feel and respond to distress in others (Hoffman, 1977).

\section{Encounter}

The "encounter" dimension of the compassion-scape includes the agent-to-recipient relationship (Box C), which in tourism discourses is mostly situated as a tourist-to-resident encounter, and in ecotourism or other nature-based forms of tourism, as a tourist-toenvironment dynamic (Weaver \& Lawton, 2007). Less prevalent is a tourist-to-tourist interaction, although there are contexts such as cruise ship disease outbreaks (Neri et al, 2008), natural disasters (Sharpley, 2005), and war commemorations (Ryan, 2007), where selected fellow tourists (e.g. injured tourists, war veterans) are perceived as immediate and deserving subjects of compassionate feeling and intervention. Although compassion to visitors is one Islamic injunction, the resident-to-tourist vector is also less prevalent given proclivities for positioning residents as the primary victimized party. Yet, it may be the visiting friend or relative who is the distressed party in VFR situations, or the victim of crime or other mishaps. Destination marketing campaigns often exhort locals to welcome tourists, but seldom in a way that embodies or implies the necessity of compassion. A difficulty in ascertaining resident reactions toward tourists is that attitudinal studies mostly focus not on tourists per se but on a broader tourism context that is not as logically amenable to compassionate actions (Easterling, 2005). 
Box C also considers businesses as an "agent", though a distinct set of agent characteristics (as per Box B) is warranted. Business-to-tourist dynamics implicate any type of business, while the business-to-resident and business-to-environment relationships would have to involve tourism businesses to be relevant to this discussion. Salient issues include how a business as a hierarchical collective of individuals notices and responds to distressful situations. As mentioned above, commitment to a CSR philosophy compels the inclusion of an ethical dimension and attention to the social good in operational considerations. Attendant policies do not explicitly advocate for compassion and may in practice be prioritized below imperatives of profitability, but they still provide a complementary basis for compassion to be activated, as for example through employee participation in local charities. Henderson (2007) describes charitable community actions taken by Phuket's hotel sector in the wake of the 2004 Boxing Day tsunami as manifestations of CSR policies, but does not consider whether those actions were acts of compassion as such or more strategic. An intriguing (and dialectical) relationship between the hotel sector and compassion is provided by Wijesinghe (2014), who cites parallel traditions of hospitality "virtue" (i.e. welcoming the stranger) and commercial "vice" (i.e. privileging profit over the greater good of society).

A second aspect is the type of encounter (Box D). Along a proximity continuum, direct personal exposure - such as might be expected in slum tourism or orphanage tourism should be most effective in eliciting feelings and response, although for some agents this entails counterproductive reactions of shock or disgust that induce retreat or confrontation. Whether the exposure is reciprocal or non-reciprocal is important, as with an agent who is "haunted" as a result of meeting the gaze and hearing the personalized plea for help from a malnourished child. Indirect exposure is a more remote option that includes observation from a distance within the destination (so that the situation is still observed in person), but also exposure from outside the destination. Pre-trip exposure might incite reactions based on 
anticipation of a visit, but the "social mediatized gaze" of virtual tourism, even where such anticipation is absent, has also been shown to attract highly emotional viewer responses, potentially including compassion (Shakeela and Weaver, 2015). Vicarious exposure refers to indirect encounters within the destination, as with hotel guests who are called upon to make charitable donations or help the environment through participation in linen re-use programs.

The final encounter aspect is the distress itself (Box E), which considers the type of suffering, the degree of distress, its ubiquity - all core elements of the compassion-scape and the situational factors that distract from or amplify the distress, including tourist characteristics as per Box A. Extreme incidents of serious injury suffered by numerous victims, especially if directly encountered, are often overwhelming and disorienting. The likelihood of having such an encounter, however, is remote. More likely, and more emblematic of resident distress in emerging economies, is personal exposure to begging. Lozanski (2013) frames repeated encounters with beggars in India as a type of felt disorientation that can be confusing and highly off-putting. Yet, the "radical potential of these contact zones" to create "more human forms of travel" (p. 48) is also recognized and framed as a subject deserving of further investigation. Gössling, Schumacher and Morelle (2004) emphasize that the interaction of tourists with marginalized resident groups has remained under-researched. Also unclear is whether awareness of tourism's or the developed world's possible role in creating or exacerbating this marginalization, as per the cautionary platform, is more likely to induce compassion from tourists. Environmental distress is a distinctive variant that can range from encounters with injured or endangered wildlife (Newsome, Dowling \& Moore, 2005) to concerns about global climate change (Scott, 2011), either extreme attracting strong reactions from wildlife and environmental advocates that implicate feelings of compassion. A relevant argument is that most tourism-related activity does not confront the high profile pain that attracts classic compassionate responses, and that much of 
the distress experienced by a community or individual is hidden or oblique, and hence more resistant to agent noticing, feeling or reaction. Tourism, moreover, tends to involve an intensive schedule of activity that encourages removal from the distress.

\section{Response}

Distress can attract negative (uncompassionate) responses (e.g. anger, confrontation, abuse), no response at all, feelings but no action, or positive (ameliorative) responses. Full articulation of the compassion-scape, and actual enablement of sustainability outcomes, occurs when both feelings and compassionate responses are instigated (Box F). Benevolent actions that occur in the absence of compassion (e.g. as non-reflexive habit, begrudged obligation, outcome of peer pressure or incentive for annoying behavior to stop) are not part of this articulation, although it may be difficult to solicit honest self-assessment of agent motivation. Actions can range from those involving personal investment of time, as embodied in volunteer tourism and extending to ex situ advocacy, to situations where an agent donates money or goods. Gössling, Schumacher and Morelle (2004) found that while a majority of tourists assisting street children in the capital city of Madagascar gave them small monetary donations, a significant minority provided them with school supplies and other beneficial goods from their home country. Such non-monetary donations may reflect concerns about the morality and consequences (e.g. dependency and exposure to robbery) that attend otherwise well-intended gifts of money. Purchasing goods and services that are not desired or not competitively priced (e.g. buying soda from a poor street vendor rather than a large grocery chain) is another more subtle response option, though its prevalence is unknown and its motivations more opaque (e.g. it may simply be a more convenient consumer option). Finally, restraint is an "action" that expresses compassion in the void by refraining from criticism, trespassing or carrying out other harm-causing actions. 
Other elements which attend the response dimension are the recipients and timeframe of compassionate actions (Boxes $\mathrm{G}$ and $\mathrm{H}$ respectively). Parallel to the goal spectrum are increasingly inclusive recipient foci on specific individuals (e.g., the beggar), the specific group (all beggars), the broader community (all residents), and the species (all people). Each, sequentially, has a more impersonal but broader implication for the attainment of sustainable tourism outcomes (see following section). Responses, moreover, can be made directly to the recipient or through an intermediary such as a charity, NGO or government entity. Inclusion of the environment expands the horizon to an entire region or Planet Earth in general. Timeframe also has sustainability implications in that it can range from an immediate and once-only act to actions repeated over the long term. Many intermediate options exist, including once-only deferred actions (e.g. a donation made to a charity upon returning home). Finally, the intentions of the response are germane (Box I). The most superficial but visceral option is the temporary alleviation of current distress, attained for example by giving a beggar sufficient money to purchase a meal. More ambitious is the termination of the distress, and then the termination of all or certain types of serious distress with the goal of improving quality of life and happiness. To the extent that poverty and other distresses are consequences of systemic forces, this implicates a broader goal of emancipation that adheres to the ideology of those advocating revolutionary change, as in contexts of justice tourism (HigginsDesbiolles, 2008) and volunteer tourism (McGehee, 2012). Such critics argue that compassion otherwise can be wielded as a powerful tool or window dressing to support a cruel and unjust status quo, as when a ruling class is exhorted to extend compassion, but not emancipation, to the ruled. 


\section{Implications for Sustainability}

Box $\mathrm{J}$ of the compassion-scape considers the attainment of tangible sustainable tourism goals as a consequence of the responses outlined above; here the connections between compassion and sustainable tourism outcomes are most explicit. Most laudable outcomes implicate at least two dimensions of the "triple bottom line" (Elkington, 1997). For example, poverty and disease alleviation - a goal with strong connections to the compassion directed toward beggars and the poor more generally - should be situated as a holistic economic, socio-cultural and environmental phenomenon. The same pertains to the cognate goal of greater societal equity, which with poverty alleviation, local empowerment and all other objectives, fosters improved quality of life. Unlike the agent's response to begging (an obvious form of distress), many sustainable tourism objectives involve more subtle forms of suffering and more nuanced responses. Reduced leakages and better quality employment, for example, derive from conscious decisions to purchase local products (economic dimension), which in turn support the articulation of the local sense of place (socio-cultural dimension). Unlike spontaneous encounters with beggars, these implicate perhaps a less emotive and more strategic type of compassionate response. Similarly, "intelligent commodification" (our term) suggests that commercialization is unavoidable in tourism but that tourist actions can help ensure that respect for and integrity of local culture is maintained.

Environmental implications include the protection of biodiversity or its restoration where the latter has been already compromised, and appropriate mitigation or adaptation responses to climate change. A challenge in either case is the tendency of tourists to respond to degradation by diverting to better endowed destinations. The framework of tourist response to climate change devised by Gössling et al (2012), for example, does not allow for the scenario of noticing, feeling emotions about, and responding compassionately to climate change in a particular destination. Relevant here is the cultivation of destination loyalty, 
wherein visitors (usually repeat) are alleged to develop a sense of stewardship toward cherished places which attracts emotional feelings and willingness to perform beneficial actions in response to perceived environmental distress (Weaver \& Lawton, 2011). At a more pedestrian level, reducing waste residuals and refraining from harmful behavior represent convenient yet still beneficial actions that require minimal investment of time or energy, but, through appropriate social construction, provide a foundation for future altruistic and compassionate behavior (Lounsbury, Ventresca \& Hirsch, 2003; Weaver, 2013).

\section{Intervention}

A critical link in the compassion-scape is intervention to induce compassionate responses. Key requirements are vested interests with both desire and resources to achieve one or more sustainable tourism goals as per Box J. Emphasized linking to Context implies that intervention primarily plays on agent characteristics to initiate compassionate behavior, but intervention also involves elements of encounter and response, potentially occurring for example in the virtual tourism environment (Box D) and focusing on volunteering activity (Box F). Among the potential strategies (Box K) available to attraction and destination managers to evoke compassionate responses is "mindful interpretation" that portrays victims sympathetically to elicit compassionate feelings and responses (Moscardo, 1996). The resultant fostering of empathy is regarded by Miles (2002) and Stone and Sharpley (2008) as critical to the success of dark tourism and, we contend, a potential precursor to compassionate behavior. The possibility of interpretation that transforms tourist attitudes and mental states has been investigated in environmental (Orams, 1996) and social contexts (Coghlan \& Gooch, 2011) though empirical evidence for such meritorious outcomes is thin. Insight into the potential, however, is provided by revelations of emotional and transformative visitor reaction to Holocaust sites (Cohen, 2011). 
Also relevant is social marketing, aiming to achieve desirable social and environmental outcomes (Kotler \& Zaltman, 1971). A broader reach is implied here than pertains to the interpretation that might occur at a particular site and time, although such differences are increasingly reduced through the rapid diffusion of social media. Like mindful interpretation, social marketing strategies, preferably carried out by an NGO or other specialized entity such as the UNWTO, must be cognizant of the target market and clear about its intentions for the behavior of that market and outcomes for affected destinations. Despite its considerable potential to achieve change, the tourism literature has barely begun to engage with the concept (Truong \& Hall, 2013; Hall, forthcoming). One consideration, germane to all forms of intervention, is differential susceptibility. Hume (2010) maintains that Generation Y members will tend to "not seek out change if it is not cost-effective, convenient and self-serving" (p. 392), raising questions as to whether the framework for engaging this cohort is inherently contradictory or a viable expression of resolution-based dialectics (Weaver, 2014). Finally, recourse to faith injunction recognizes that a substantial portion of potential tourists in many countries (e.g. USA) claims to be religious. If compassionate behavior is a universal expectation of such religions, then faith organizations such as churches, mosques and temples are obliged to encourage compassionate behavior by adherents when they travel, regardless of motivations or travel purpose.

\section{Conclusion}

The proposed framework is the first concerted engagement with compassion in the tourism literature and as such is conceptual rather than empirical in approach. It can help to "make things better" by outlining the anatomy of contexts, encounters and compassionate responses that may yield specific and tangible sustainable tourism outcomes. Informed by appropriate interventions and bearing in mind that "compassion is not easy" (Von Dietze \& Orb, 2000, p. 169), these could eventually entail predictable and collective patterns of 
compassionate behavior that positively change the sector as a whole. As befits an exploratory paper, this "compassion-scape" is tentative and ambitiously panoramic, so that each element can be considered here only briefly; deletions, consolidations and additions, as warranted, are welcome, as is specialist scrutiny by sociologists, psychologists, philosophers, etc. and follow-up empirical research. In-depth engagement of each component, initially, is merited given the potential of compassion to motivate actions that manifest sustainable tourism, notwithstanding the many attendant uncertainties. That compassion is seemingly universal rather than ethnocentric amplifies this potential at a time when sustainability is being positioned increasingly as a relative process or outcome that varies according to destination context and idiosyncrasy. Positioning compassion more centrally within all sustainability and sustainable tourism discourses, however, poses several challenges. It is worth noting epistemologically that while positivist research is criticized for reflecting "sterile scholarship" that denies much of what human experience is all about (Pritchard, Morgan \& Ateljevic, 2011, p. 952), the emotional, spiritual and subjective remain largely opaque, diffuse and marginalized - at least within tourism studies (Tribe, 2008) - and open to suspicion and skepticism from scholars who do not believe that the outcomes from such inquiry are sufficiently valid or reliable (Smith, 2010). Compassion appears to be a "real" phenomenon that most of us have experienced, but it is embedded intensively within this emotive subjective context and presents therefore many innate methodological challenges to the interested researcher.

Not the least of these challenges is the difficulty in articulating and measuring the "compassionate spark" that ignites beneficial actions, though measurement of sustainability is a problem that pervades sustainable tourism (Liu, 2003). Recent foci on transformative experiences, mindfulness, emotions (Jepson \& Sharpley, 2014) and other more subjective aspects of sustainability have promise for facilitating such research and narrowing the gap 
between good intentions and good behavior. Another avenue is increased engagement between tourism and "positive psychology" (Pearce, 2009). For achieving effective intervention, there is also ample room for applying to compassion popular theories that attempt to explain and predict human behavior, including social identity theory, social representations theory, social exchange theory, and the theory of planned behavior. For the latter, key variables such as behavioral beliefs and attitudes as well as subjective norms and control beliefs reinforce the focus of intervention on the agent context, as per Box B, to foster facilitative intentions. Lack of attention to emotional variables, however, impedes the model's overall efficacy for predicting compassionate behavior. Social exchange theory has utility for its accommodation of reciprocity but also morality, justice and the building of long term relationships based on mutual trust and cooperation (Cropanzano \& Mitchell, 2005); how the attendant "exchange rules" could be applied to compassionate behavior in tourism settings is a worthy topic of investigation. There is additional promise in the application of Goffman's (1959) ideas of social performance, which situate potential and actual agents and recipients of compassion as "actors" whose behavior is dictated by an array of considerations related to perceptions of self and other, expectations, desired impressions, gain or loss of face, mutual understanding of context, etc. These in turn are mediated by the extent to which actor encounters occur in the six frontstage/backstage gradations identified by MacCannell (1976).

It was proposed in the Introduction of this paper that compassion is a potential enabler of various aspirational forms of sustainable tourism that currently lack traction. More specifically, compassion can be mobilized to achieve the emancipation desired by justice tourism and hopeful tourism, the poverty alleviation desired by pro-poor tourism, the climate change mitigation and sense of place desired by slow tourism, and the quality employment and leakage reduction sought by fair trade tourism. As for more clearly articulated products, 
volunteer tourism, slum tourism, orphanage tourism and religious tourism are all activities which clearly implicate compassion and therefore logical priorities for applying the compassion-scape. However, there is a paramount need to engage and reform conventional mass tourism which, by definition, accounts for most global tourism activity and concomitantly most of its economic, sociocultural and environmental impacts. A growing literature on the need for ethics in all forms of tourism is already establishing a strong basis for such engagement (Fennell, 2000, 2006a; Macbeth, 2005), as is the emerging literature on altruism and tourism (Coghlan \& Fennell, 2009; Fennell, 2006b). Compassion, accordingly, accompanies and reinforces ethics as a core alternative tourism contribution to Weaver's (2014) enlightened mass tourism synthesis. Pro-poor tourism, religious tourism and fair trade tourism in particular have inherent merit and potential as mass-alternative tourism syntheses compatible with enlightened mass tourism, but we argue that they are most likely to achieve traction and realize their aspirational outcomes by engaging and assimilating the precursor ingredient of compassion.

\section{References}

Aguiló, E. \& Rosselló, J. (2005). Host community perceptions: A cluster analysis. Annals of Tourism Research, 32, 925-941.

Ashley, C., Roe, D., \& Goodwin, H. (2001). Pro-poor Tourism Strategies: Making Tourism Work for the Poor: A Review of Experience. Manchester, UK: Centre for Responsible Tourism.

Backer, E. (2012). VFR travel: It is underestimated. Tourism Management, 33, 74-79.

Becken, S. \& Hay, J. (2007). Tourism and Climate Change: Risks and Opportunities. Clevedon, UK: Channel View. 
Bramwell, B. (Ed.) (2004). Coastal Mass Tourism: Diversification and Sustainable Development in Southern Europe. Clevedon, UK: Channel View.

Bryden, J. (1973). Tourism and Development: A Case Study of the Commonwealth Caribbean. London: Cambridge University Press.

Butler, R. \& Boyd, S. (Eds.) (2000). Tourism and National Parks: Issues and Implications. Chichester, UK: Wiley.

Campo-Martínez, S., Garau-Vadell, J., \& Martínez-Ruiz, M. (2010). Factors influencing repeat visits to a destination: The influence of group composition. Tourism Management, 31, 862-870.

Chambers, D., \& Buzinde, C. (2015). Tourism and decolonisation: Locating research and self. Annals of Tourism Research, 51, 1-16.

Chok, S., Macbeth, J. \& Warren, C. (2007). Tourism as a tool for poverty alleviation: A critical analysis of 'pro-poor tourism' and implications for sustainability. Current Issues in Tourism, 10, 144-165.

Clark, C. (1997). Misery and Company: Sympathy in Everyday Life. Chicago: The University of Chicago Press.

Cleverdon, R. \& Kalisch, A. (2000). Fair trade in tourism. International Journal of Tourism Research, 2, 171-187.

Coghlan, A. \& Fennell, D. (2009). Myth or substance: An examination of altruism as the basis of volunteer tourism. Annals of Leisure Research, 12, 377-402.

Coghlan, A. \& Gooch, M. (2011). Applying a transformative learning framework to volunteer tourism. Journal of Sustainable Tourism, 19, 713-728. 
Cohen, E. (1992). Pilgrimage centres: Concentric and excentric. Annals of Tourism Research, $19,33-50$.

Cohen, E. (2011). Educational dark tourism at an in populo site: The Holocaust Museum in Jerusalem. Annals of Tourism Research, 38, 193-209.

Collins-Kreiner, N., \& Kliot, N. (2000). Pilgrimage tourism in the Holy Land: The behavioural characteristics of Christian pilgrims. GeoJournal, 50, 55-67.

Cropanzano, R. \& Mitchell, M. (2005). Social exchange theory: An interdisciplinary review. Journal of Management, 31, 874-900.

Deery, M., Jago, L., \& Fredline, L. (2012). Rethinking social impacts of tourism research: A new research agenda. Tourism Management, 33, 64-73.

de Kadt, E. (1984). Tourism: Passport to Development? Perspective on the Social and Cultural Effects of Tourism in Developing Countries. Oxford: Oxford University Press.

Din, K. (1989). Islam and tourism: Patterns, issues, and options. Annals of Tourism Research, $16,542-563$.

Duffy, R. \& Moore, L. (2011). Global regulations and local practices: The politics and governance of animal welfare in elephant tourism. Journal of Sustainable Tourism, 19, (4\&5), 589-604.

Eade, J. (1992). Pilgrimage and tourism at Lourdes, France. Annals of Tourism Research, 19, $18-32$.

Easterling, D. (2005). The residents' perspective in tourism research: a review and synthesis. Journal of Travel \& Tourism Marketing, 17(4), 45-62. 
Eisenberg, N. \& Miller, P. (1987). Empathy, sympathy and altruism: Empirical and conceptual links. In N. Eisenberg \& J. Strayer (Eds.), Empathy and its Development. Cambridge: Cambridge University Press, pp. 292-316.

Elkington, J. (1997). Cannibals with Forks: The Triple Bottom Line of $21^{\text {st }}$ Century Business. London: Oxford University Press.

Farbotko, C. (2010). 'The global warming clock is ticking so see these places while you can': Voyeuristic tourism and model environmental citizens on Tuvalu's disappearing islands. Singapore Journal of Tropical Geography, 31, 224-238.

Fennell, D. (2000). Tourism and applied ethics. Tourism Recreation Research, 25 (1), 59-69.

Fennell, D. (2006a). Tourism Ethics. Clevedon, UK: Channel View.

Fennell, D. (2006b). Evolution in tourism: The theory of reciprocal altruism and tourist-host interactions. Current Issues in Tourism, 9, 105-124.

Fennell, D. (2014). Exploring the boundaries of a new moral order for tourism's global code of ethics: An opinion piece on the position of animals in the tourism industry. Journal of Sustainable Tourism, 22 (7), 983-996.

Frenzel, F., Koens, K., \& Steinbrink, M. Eds. (2012). Slum Tourism: Poverty, Power and Ethics. New York: Routledge.

Frynas, J. (2005). The false developmental promise of Corporate Social Responsibility: Evidence for multinational oil companies. International Affairs, 81, 581-598.

Gilbert, P. (2005). Introduction and outline. In P. Gilbert (Ed.) Compassion: Conceptualisations, Research and Use in Psychotherapy (pp. 1-6). New York: Routledge. 
Glover, T. \& Filep, S. (2015). On kindness of strangers in tourism. Annals of Tourism Research, 50, 159-172.

Goetz, J., Keltner, D., \& Simon-Thoms, E. (2010). Compassion: An evolutionary analysis and empirical review. Psychological Bulletin, 136, 351-374.

Goffman, E. (1959). The Presentation of Self in Everyday Life. Garden City, NJ: Doubleday.

Goldstein, N., Cialdini, R., \& Griskevicius, V. (2008). A room with a viewpoint: Using social norms to motivate environmental conservation in hotels. Journal of Consumer Research, 35, 472-482.

Gössling, S., Schumacher, K., and Morelle, M. (2004) Tourism and street children in Antananarivo, Madagascar. Tourism and Hospitality Research, 5, 131-149.

Gössling, S., Scott, D., Hall, C., Ceron, J-P., \& Dubois, G. (2012). Consumer behaviour and demand response of tourists to climate change. Annals of Tourism Research, 39, 36-58.

Grimm, K., \& Needham, M. (2012). Moving beyond the "I" in motivation: Attributes and perceptions of conservation volunteer tourists. Journal of Travel Research, 51, 488501.

Grühn, D., Rebucal, K., Diehl, M., Lumley, M., \& Labouvie-Vief, G. (2008). Empathy across the adult lifespan: Longitudinal and experience-sampling findings. Emotion, 8, 753765.

Gunter, H. (2005). Hotels balance business, compassion. Hotel \& Motel Management, $220(17), 4,44$. 
Hall, C.M. (forthcoming) Intervening in academic interventions: framing social marketing's potential for successful sustainable tourism behavioural change Journal of Sustainable Tourism DOI: 10.1080/09669582.2015.1088861

Hardy, A., Beeton, R., \& Pearson, L. (2002). Sustainable tourism: An overview of the concept and its position in relation to conceptualisations of tourism. Journal of Sustainable Tourism, 10 (6), 475-496.

Harrison, D. (2008). Pro-poor tourism: A critique. Third World Quarterly, 29, 851-868.

Henderson, J. (2007). Corporate social responsibility and tourism: Hotel companies in Phuket, Thailand, after the Indian Ocean tsunami. International Journal of Hospitality Management, 26, 228-239.

Higgins-Desbiolles, F. (2008). Justice tourism and alternative globalisation. Journal of Sustainable Tourism, 16 (3), 345-364.

Hoffman, M. (1977). Sex differences in empathy and related behaviors. Psychological Bulletin, 84, 712-722.

Hogan, R. (1969). Development of an empathy scale. Journal of Consulting and Clinical Psychology, 33, 307-316.

Hultsman, J. (1995). Just tourism: An ethical framework. Annals of Tourism Research, 22, $553-567$.

Hume, M. (2010). Compassion without action: Examining the young consumers consumption and attitudes to sustainable consumption. Journal of World Business, 45, 385-394. 
Hung, K., \& Petrick, J. (2012). Testing the effects of congruity, travel constraints, and selfefficacy on travel intentions: An alternative decision-making model. Tourism Management, 33, 855-867.

Jafari, J. (2001). The scientification of tourism. In Smith, V. \& Brent, M. (Eds.). Hosts and Guests Revisited: Tourism Issues of the $21^{\text {st }}$ Century. New York: Cognizant, pp. 28-41.

Jepson, D. \& Sharpley, R. (2015). More than sense of place? Exploring the emotional dimension of rural tourism experiences. Journal of Sustainable Tourism. Doi: 10.1080/09669582.2014.953543.

Kanov, J., Maitlis, S., Worline, M., Dutton, J., Frost, P., \& Lilius, J. (2004). Compassion in organizational life. American Behavioral Scientist, 47, 808-827.

Khalil, E. (2004). What is altruism? Journal of Economic Psychology, 25, 97-123.

Kotler, P. \& Zaltman, G. (1971). Social marketing: An approach to planned social change. Journal of Marketing, 35, 3-12.

Langer, E. (1989). Mindfulness. Reading: Addison-Wesley.

Lashley, C. \& Morrison, A. (2011). In Search of Hospitality: Theoretical Perspectives and Debates. Abingdon, UK: Routledge.

Laurenson, P. \& Collins, D. (2007). Beyond punitive regulation? New Zealand local governments' responses to homelessness. Antipode, 39, 649-667.

Lea, J. (1988). Tourism and Development in the Third World. London: Routledge.

Liu, Z. (2003). Sustainable tourism development: A critique. Journal of Sustainable Tourism, $11(6), 459-475$. 
Lounsbury, M., Ventresca, M., \& Hirsch, P. (2003). Social movements, field frames and industry emergence: A cultural-political perspective on US recycling. Socio-Economic Review, 1, 71-104.

Lozanski, K. (2013). Encountering beggars: Disorienting travelers? Annals of Tourism Research, 42, 46-64.

Lumsdon, L. \& McGrath, P. (2011). Developing a conceptual framework for slow travel: A grounded theory approach. Journal of Sustainable Tourism, 19(3), 265-279.

Macbeth, J. (2005). Towards an ethics platform for tourism. Annals of Tourism Research, 32, 962-984.

MacCannell, D. (1976). The Tourist: A New Theory of the Leisure Class. New York: Schocken Books.

Matheson, A. \& Wall, G. (2006). Tourism: Change, Impacts and Opportunities. Harlow: Pearson Prentice Hall.

Matos, W. (2004). Can slow travel bring new life to the Alpine regions? In Weiermair, K. \& Mathies, C. (Eds.). The Tourism and Leisure Industry. New York: Haworth, pp. 93103.

Mbaiwa, J. (2005). The problems and prospects of sustainable tourism development in the Okavango Delta, Botswana. Journal of Sustainable Tourism, 13(3), 203-227.

McGehee, N. (2012). Oppression, emancipation, and volunteer tourism. Annals of Tourism Research, 39, 84-107.

McIntosh, A. \& Zahra, A. (2007). A cultural encounter through volunteer tourism: Towards the ideals of sustainable tourism? Journal of Sustainable Tourism, 15(5), 541-556. 
Miles, W. (2002). Auschwitz: Museum interpretation and darker tourism. Annals of Tourism Research, 29, 1175-1178.

Miller, T., Grimes, M., McMullen, J., \& Vogus, T. (2012). Venturing for others with heart and head: How compassion encourages social entrepreneurship. Academy of Management Review, 37, 616-640.

Moeller, S. (1999). Compassion Fatigue: How the Media Sell Disease, Famine, War, and Death. London: Routledge.

Moscardo, G. (1996). Mindful visitors: Heritage and tourism. Annals of Tourism Research, 23, 376-397.

Mostafanezhad, M. (2013). The geography of compassion in volunteer tourism. Tourism Geographies, 15, 318-337.

Mowforth, M., \& Munt, I. (2008). Tourism and Sustainability: Development, Globalisation and New Tourism in the Third World. Abingdon, UK: Routledge.

Nankervis, A. (2009). Vulnerability analysis and sustainability in tourism: Lessons from Phuket. In. C. Pforr \& P. Hosie (Eds.) Crisis Management in the Tourism Industry: Beating the Odds? (pp. 93-105). Farnham, UK: Ashgate.

Neri, A., Cramer, E., Vaughan, G., Vinjé, J., \& Mainzer, H. (2008). Passenger behaviors during Norovirus outbreaks on cruise ships. Journal of Travel Medicine, 15, 172-176.

Newsome, D., Dowling, R., \& Moore, S. (2005). Wildlife Tourism. Clevedon, UK: Channel View.

Omoto, A. Malsch, A., \& Barraza, J. (2009). Compassionate acts: Motivations for and correlates of volunteerism among older adults. In B. Fehr, S. Sprecher \& L. Underwood 
(Eds.), The Science of Compassionate Love: Theory, Research and Applications.

Chichester, UK: Blackwell, pp. 257-282.

Orams, M. (1995). Using interpretation to manage nature-based tourism. Journal of Sustainable Tourism, 4(2), 81-94.

Pearce, D. (1989). Tourist Development. Second Edition. Harlow: Longman.

Pearce, P. (2009). The relationship between positive psychology and tourist behavior studies. Tourism Analysis, 14, 37-48.

Pizam, A. (1978). Tourism's impacts: The social costs to the destination community as perceived by its residents. Journal of Travel Research, 16(4), 8-12.

Pritchard, A., Morgan, N., \& Ateljevic, I. (2011). Hopeful tourism: A new transformative perspective. Annals of Tourism Research, 38, 941-963.

Raj, R. \& Morpeth, N. Eds. (2007). Religious Tourism and Pilgrimage Management: An International Perspective. Wallingford, UK: CABI.

Reas, P. (2012). 'Boy, have we got a vacation for you': Orphanage tourism in Cambodia and the commodification and objectification of the orphaned child. Thammasat Review, 16, 121- 139.

Ryan, C. Ed. (2007). Battlefield Tourism: History, Place and Interpretation. London: Routledge.

Scheyvens, R. (2002). Tourism for Development: Empowering Communities. Harlow: Prentice-Hall.

Scott, D. (2011). Why sustainable tourism must address climate change. Journal of Sustainable Tourism, 19 (1), 17-34. 
Scott, D., Hall, C., \& Gössling, S. (2012). Tourism and Climate Change: Impacts, Adaptation and Mitigation. London: Routledge.

Shakeela, A., \& Weaver, D. (2015). The exploratory social-mediatized gaze: Reactions of virtual tourists to an inflammatory YouTube incident. Journal of Travel Research. Doi: $10.1177 / 0047287514532369$.

Shakeela, A., \& Weaver, D. (2012). Resident reactions to a tourism incident: Mapping a Maldivian emoscape. Annals of Tourism Research, 39, 1337-1358.

Sharpley, R. (2005). The tsunami and tourism: A comment. Current Issues in Tourism, 8, 344-349.

Singh, T. (2002). Altruistic tourism: Another shade of sustainable tourism. Tourism (Zagreb), $50,361-370$.

Smith, S. L. J. (2010). Practical Tourism Research. Wallingford, UK: CABI.

Smith, V. (Ed.) (1989). Hosts and Guests: The Anthropology of Tourism. Second Edition Philadelphia: University of Pennsylvania Press.

Smith, V. \& Eadington, W. (Eds.) (1992). Tourism Alternatives: Potentials and Problems in the Development of Tourism. Philadelphia: University of Pennsylvania Press.

Stone, P. \& Sharpley, R. (2008). Consuming dark tourism: A thanatological perspective. Annals of Tourism Research, 35, 574-595.

Tourism Concern (2014). Tourism Concern: Annual Report and Account 2013/14. Retrieved on December 3, 2014 from http://www.tourismconcern.org.uk/uploads/Annual\%20Report\%202013:14\%20(web).p df. 
Tribe, J. (2008). Tourism: A critical business. Journal of Travel Research, 46, 245-255.

Trivers, R. (1971). The evolution of reciprocal altruism. The Quarterly Review of Biology, $46,35-57$.

Truong, V. \& Hall, C. (2013). Social marketing and tourism: What is the evidence? Social Marketing Quarterly, 19, 110-135.

Van Kleef, G., Oveis, C., van der Löwe, LuoKogan, A., Goetz, J., \& Keltner, D. (2008). Power, distress, and compassion: Turning a blind eye to the suffering of others. Psychological Science, 19, 1315-1322.

Von Dietze, E. \& Orb, A. (2000). Compassionate care: A moral dimension of nursing. Nursing Inquiry, 7, 166-174.

Wallace, B. (2005). Genuine Happiness: Meditation as the Path to Fulfillment. Hoboken, NJ: Wiley.

Wearing, S., \& McGehee, N. (2013). Volunteer tourism: A review. Tourism Management, $38,120-130$.

Weaver, D. (2007). Toward sustainable mass tourism: Paradigm shift or paradigm nudge? Tourism Recreation Research, 32(3), 65-69.

Weaver, D. (2012). Organic, incremental and induced paths to sustainable mass tourism convergence. Tourism Management, 33, 1030-1037.

Weaver, D. (2013). Protected area visitor willingness to participate in site enhancement activities. Journal of Travel Research, 52, 377-391.

Weaver, D. (2014). Asymmetrical dialectics of sustainable tourism: Toward enlightened mass tourism. Journal of Travel Research, 53, 131-140. 
Weaver, D., \& Lawton, L. (2007). Twenty years on: The state of contemporary ecotourism research. Tourism Management, 28, 1168-1179.

Weaver, D., \& Lawton, L. (2011). Visitor loyalty at a private South Carolina protected area. Journal of Travel Research, 50, 335-346.

Weaver, D., \& Lawton, L. (2014). Tourism Management. Fifth Edition. Milton, Qld: Wiley Australia.

Wijesinghe, G. (2014). Reimagining the application of sustainability to the hospitality industry through a virtue ethics framework. Journal of Sustainable Tourism, 22 (1), 3149. 


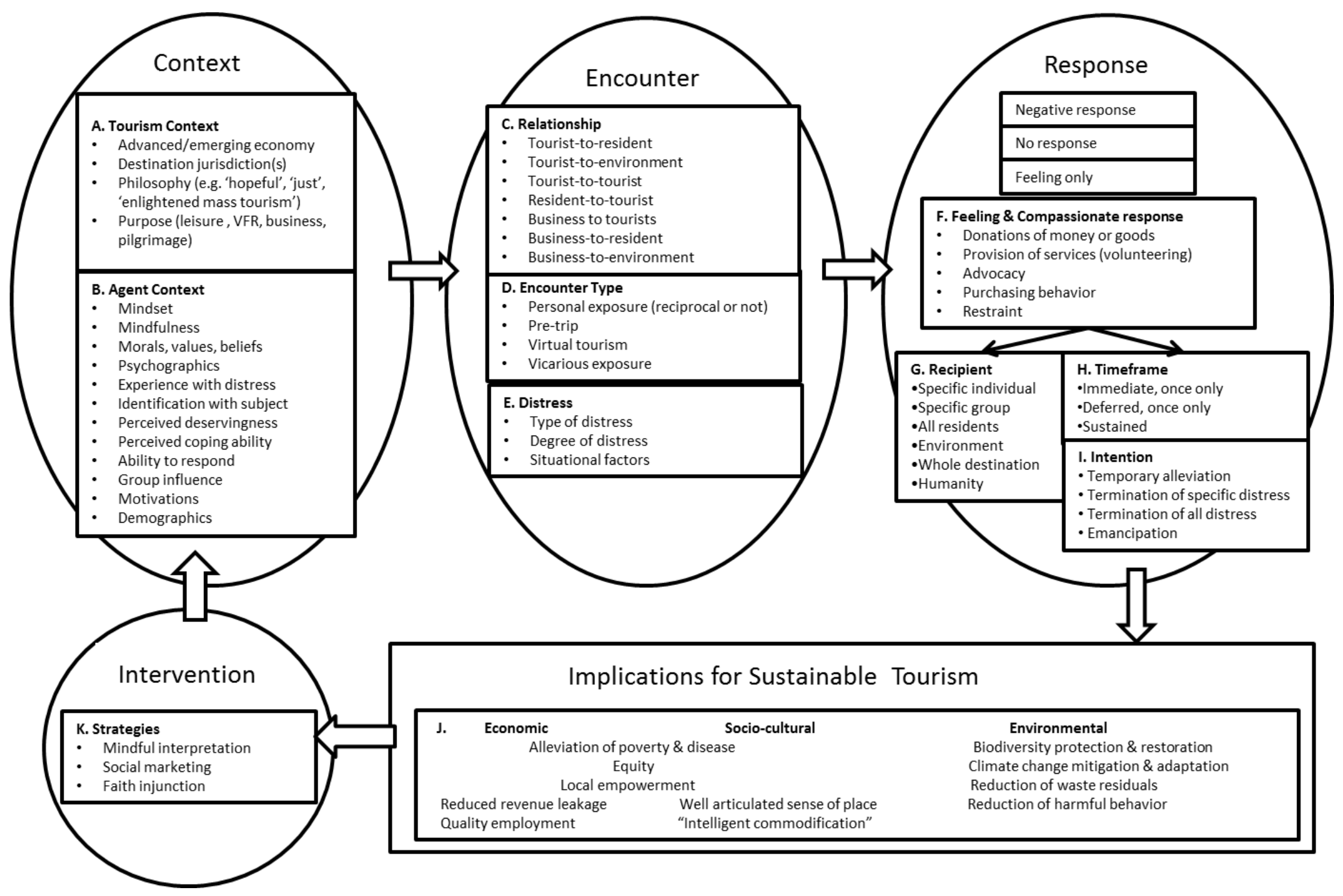

Figure 1 Sustainable Tourism Compassion-scape 